\title{
Crystal Structures of Two Substituted Pyridinecarboxylates
}

\author{
A. M. Moustafa, ${ }^{a}$ S. M. Shalaby, ${ }^{a}$ N. A. Ali, ${ }^{b}$ A. M. El-Shaabiny, ${ }^{a}$ \\ A. A. Ramadan, ${ }^{b}$ I. S. Ahmed Farag, ${ }^{a}$ and Adel S. Girgis ${ }^{a}$ \\ ${ }^{a}$ National Research Centre, Physics Section, Solid State Department, \\ Cairo, Egypt. \\ ${ }^{b}$ Physics Department, Faculty of Science, Helwan University, Helwan, \\ Cairo, Egypt.
}

Two substituted pyridinecarboxylates were synthesized; Ethyl 2-bromo4-(4-chlorophenyl)-6- phenyl-3-pyridinecarboxylate, $\mathrm{C}_{20} \mathrm{H}_{15} \mathrm{BrClNO}_{2}$ (1) and Ethyle 4-(4-chlorphenyle)-6-phenyle-2- (1-piperdinyle)-3-pyridinecarboxylate, $\mathrm{C}_{24} \mathrm{H}_{23} \mathrm{ClN}_{2} \mathrm{O}_{3}$ (2). It was found, that compound 1 belongs to the orthorhombic system with space group $\mathrm{P} 22_{1} 2_{1} 2_{1}$ and compound 2 to the triclinic system with space group $\mathrm{P} \overline{1}$. The piperidine ring in $\mathbf{2}$ has the shape of the distorted chair configuration. The crystal data of the two compounds and their atomic coordinates with the equivalent isotropic displacement parameters are presented.

\section{Introduction:}

Nicotinate (3-pyridinecarboxylate) esters represent an important class of heterocyclic compounds characterized by highly pronounced pharmacological and biological importance. Many patents have been reported towards numerous activities of various 3-pyridinecarboxylate esters as agrochemical fungicides, herbicides, $\mathrm{A}_{3}$ adenosine receptor antagonists, cholesteryl ester transfer protein inhibitors, blood circulation promoters and anti-inflammatory. Pharmacological compositions containing nicotinate esters have been also used as antidandruff, antiitching and hair loss preventing.

\section{Experimental and Calculation:}

2.1. Materials Synthesis:

A solution of bromine $(11 \mathrm{mmol})$ in glacial acetic acid $(5 \mathrm{ml})$ was added dropwise while stirring to a solution of ethyl 4-benzoyl-3(4-chlorophenyl)-2-cyanobutyrate $(10 \mathrm{mmol})$ in glacial acetic acid $(20 \mathrm{ml})$,

e-mail: aishamoustafa@yahoo.com,Fax: 2023370931 
heated at $60-70{ }^{\circ} \mathrm{C}$, for $15 \mathrm{~min}$. After complete addition, stirring was continued for $3 \mathrm{~h}$ at the same temperature. Then, the reaction mixture was stored overnight at room temperature $\left(25-30{ }^{\circ} \mathrm{C}\right)$ and poured into ice-cold water $(200 \mathrm{ml})$. The separated solid was collected, washed with water and crystallized from ethanol giving the corresponding compound $\mathbf{1}$ as colourless crystals, m.p. $123 \pm 1^{\circ} \mathrm{C}$, yield $72 \%$. The scheme is depicted in Fig. (1).

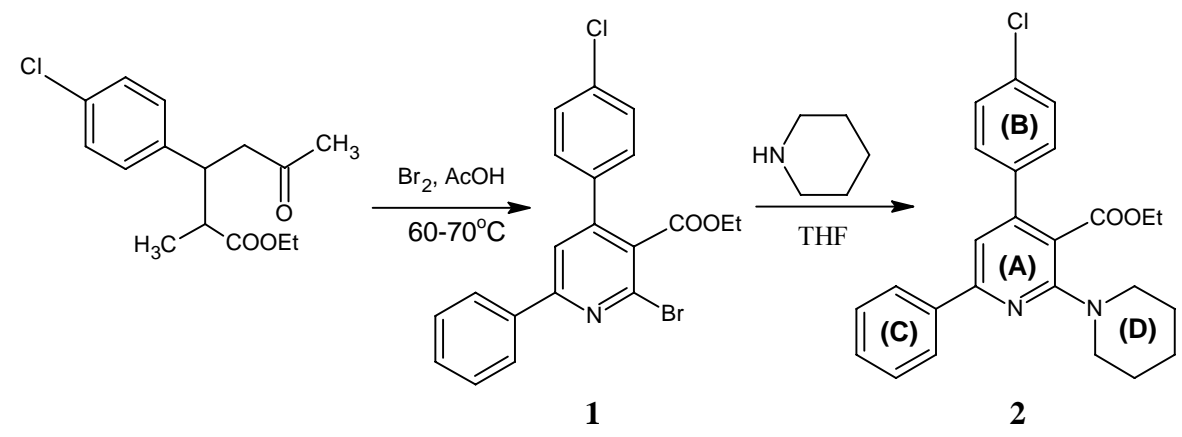

Fig. (1): Synthetic route for the titled compounds.

A mixture of compound $1(2.5 \mathrm{mmol})$ and the corresponding secondary amine $(10 \mathrm{mmol})$ in tetrahydrofuran $(20 \mathrm{ml})$ was boiled under reflux for the appropriate time. The clear reaction mixture was evaporated till dryness under reduced pressure and the residue was triturated with methanol $(5 \mathrm{ml})$. The separated solid was collected and crystallized from methanol affording the corresponding compound 2 as a colourless crystals; m.p. $105 \pm 1{ }^{\circ} \mathrm{C}$; yield $79 \%$, (Scheme 1).

\subsection{Data Collection:}

A colourless needle crystal with approximate dimensions $0.3 \times 0.4 \times 0.3$ $\mathrm{mm}$ of (1) and a colourless prismatic crystal having approximate dimensions $0.3 \times 0.4 \times 0.4 \mathrm{~mm}$ of (2) were attached to a glass fiber and mounted on an EnrafNonius 590 Kappa CCD single crystal diffractometer. X-ray diffraction data of single crystal were collected at room temperature with graphite monochromated $\operatorname{MoK} \alpha(\lambda=0.71073 \AA)$ radiation; the crystal to detector distance was $4 \mathrm{~cm}$. Cell refinement and data reduction were carried using Denzo and Scalepak programs [1]. With $\varphi-\omega$ scan mode, out of 4063 and 12521 independent reflections collected for (1) and (2), respectively, 2376 and 6176 reflections with $\mathrm{I} \geq 3 \sigma(\mathrm{I})$ were used for structure analysis. Absorption correction (multi-scan) was applied to the intensity data $(\operatorname{Tmax}=0.450, T \min =0.488$ for $(\mathbf{1})$; $\operatorname{Tmax}=$ $0.917, \operatorname{Tmin}=0.985$ for $(2))$. 


\subsection{Structure Solution and Refinement:}

The crystal structures were solved by direct method using Sir92 program [2], which revealed the positions of all non hydrogen atoms and refined by the full matrix least squares refinement based on $\mathrm{F}^{2}$ using maXus package [3]. The anisotropic displacement parameters of all non-hydrogen atoms were refined, then the hydrogen atoms were introduced as a riding model with $\mathrm{C}-\mathrm{H}=0.96 \AA$ and refined isotropically. The maximum heights in the final difference Fourier map were found to be, respectively, 0.68 and $0.50 \mathrm{e} / \AA^{3}$ for the tow compounds and the minimum heights -0.60 and $-0.74 \mathrm{e} / \AA^{3}$. The Molecular graphics were prepared using ORTEP program [4].

\section{Results and Discussion:}

In this study the crystal structures of two compounds have been solved namely; Ethyl 2-bromo-4-(4-chlorophenyl)-6-phenyl-3-pyridinecarboxylate, 1 and Ethyle (4-chlorphenyle)-6-phenyle-2-(1-piperdinyle)3-pyridinecarboxylate, 2. Figure (2) shows the Molecular structure of these two compounds, and their crystal data and other relevant parameters are given in Table (1). The atomic coordinates with their equivalent isotropic displacement factors for non-hydrogen atoms are presented in Table ( $2 \& 3)$ for compounds 1 and 2 , respectively. The equivalent displacement parameters, $\mathrm{U}_{\text {eq }}$, were calculated from the anisotropic refined parameters $\left(\mathrm{U}_{\mathrm{ij}}, \mathrm{a}_{\mathrm{i}}{ }^{*}, \mathrm{a}_{\mathrm{j}}{ }^{*}, \mathrm{a}_{\mathrm{i}}\right.$ and $\left.\mathrm{a}_{\mathrm{j}}\right)$ according to:

$$
\mathrm{U}_{\mathrm{eq}}=1 / 3\left[\Sigma_{\mathrm{i}} \Sigma_{\mathrm{j}} \mathrm{U}_{\mathrm{ij}} \mathrm{a}_{\mathrm{i}} * \mathrm{a}_{\mathrm{j}} * \mathrm{a}_{\mathrm{i}} \cdot \mathrm{a}_{\mathrm{j}}\right]
$$

and are given in Tables ( $2 \& 3)$.

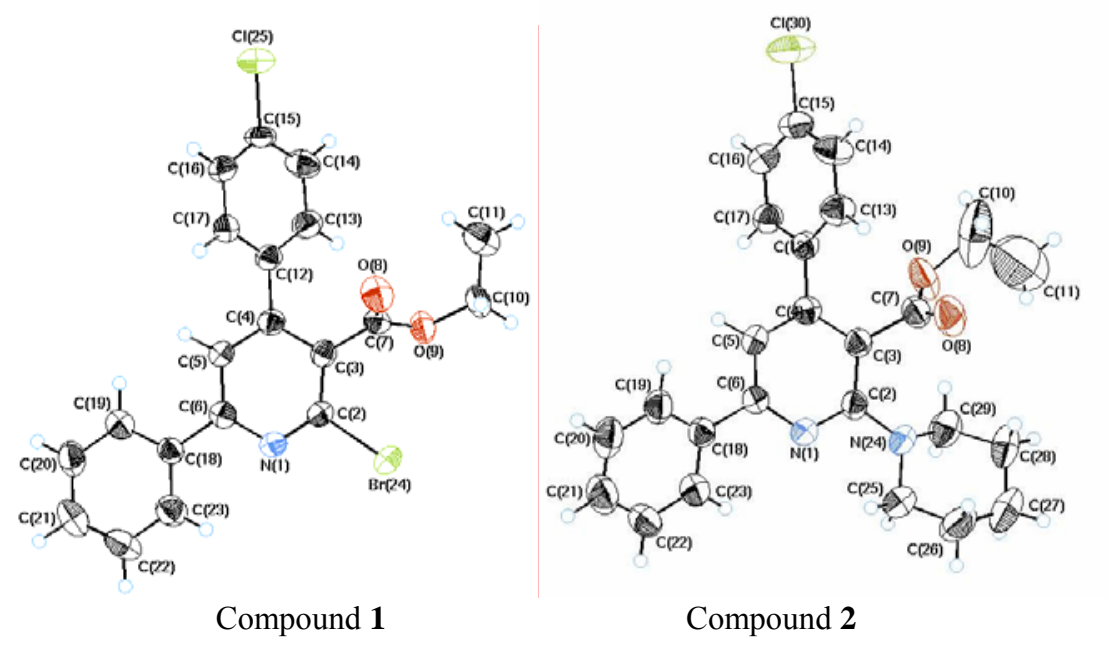

Fig. (2): Molecular structure of the two compounds showing 50\% probability ellipsoids. 
The basic unit of theses compounds consists mainly of pyridine ring (A), chlorphenyl ring (B), phenyl ring (C) and carboxylate group. They differ only in the attachment at the position (C2) of the pyridine ring, where $\mathbf{1}$ has bromine atom and $\mathbf{2}$ has piperidine ring (D). Compound $\mathbf{1}$ belongs to the orthorhombic system with space group $\mathrm{P} 2{ }_{1} 2_{1} 2_{1}$ and compound 2 to the triclinic system with space group $\mathrm{P} \overline{1}$. The piperdine ring in $\mathbf{2}$ has the distorted chair configuration.

Table 1: Crystal Data and details of structure determination.

\begin{tabular}{|c|c|c|}
\hline & Compound 1 & Compound 2 \\
\hline CCDC Number & 279948 & 279949 \\
\hline Empirical formula & $\mathrm{C}_{20} \mathrm{H}_{15} \mathrm{BrClNO}_{2}$ & $\mathrm{C}_{25} \mathrm{H}_{25} \mathrm{ClN}_{2} \mathrm{O}_{2}$ \\
\hline Molecular weight & 416.707 & 420.940 \\
\hline Temperature $(\mathrm{K})$ & 298 & 298 \\
\hline Wavelength & 0.71073 & 0.71073 \\
\hline Crystal system & Orthorhombic & Triclinic \\
\hline Space group & $\mathrm{P} 2_{1} 2_{1} 2_{1}$ & $\mathrm{P} \overline{1}$ \\
\hline Unit cell dimensions $\left(\AA,^{\circ}\right)$ & $\begin{array}{c}a=8.4227(2) \\
b=9.2683(2) \\
c=23.0786(6) \\
\alpha=90.00 \\
\beta=90.00 \\
\gamma=90.00\end{array}$ & $\begin{array}{c}a=10.6580(3) \\
b=10.7504(3) \\
c=11.0155(4) \\
\alpha=92.8002(14) \\
\beta=95.3227(14) \\
\gamma=117.3631(13)\end{array}$ \\
\hline Volume $\left(\AA^{3}\right)$ & $1801.61(7)$ & $1110.09(6)$ \\
\hline $\mathrm{Z}$ & 4 & 2 \\
\hline Calculated density $\left(\mathrm{g} \mathrm{cm}^{-3}\right)$ & 1.536 & 1.259 \\
\hline $\mathrm{F}(000)$ & 840 & 444 \\
\hline Crystal size $(\mathrm{mm})$ & $0.3 \times 0.4 \times 0.3$ & $0.3 \times 0.4 \times 0.4$ \\
\hline$\theta$ range for data collection & $2.910-27.49^{\circ}$ & $2.910-26.36^{\circ}$ \\
\hline Index ranges & $\begin{array}{l}0 \leq \mathrm{h} \leq 10 \\
0 \leq \mathrm{k} \leq 12 \\
-29 \leq 1 \leq 29\end{array}$ & $\begin{array}{l}-13 \leq \mathrm{h} \leq 13 \\
-13 \leq \mathrm{k} \leq 13 \\
0 \leq 1 \leq 13\end{array}$ \\
\hline Reflections collected & 4063 & 4516 \\
\hline Independent reflections & 2376 & 1803 \\
\hline Refinement method & $\begin{array}{l}\text { Full-matrix least-squares } \\
\text { on } \mathrm{F}^{2}\end{array}$ & $\begin{array}{l}\text { Full-matrix least-squares } \\
\text { on } \mathrm{F}^{2}\end{array}$ \\
\hline Data / restraints / parameters & $2376 / 0 / 226$ & $1803 / 0 / 271$ \\
\hline Goodness-of-fit (all data) & 1.010 & 0.964 \\
\hline $\mathrm{R}$ indices (all data) & $\mathrm{R}=0.069 \mathrm{wR}=0.074$ & $\mathrm{R}=0.124 \quad \mathrm{wR}=0.104$ \\
\hline Final $R$ indices $[\mathrm{I}>3 \operatorname{sigma}(\mathrm{I})]$ & 0.031 & 0.045 \\
\hline$\Delta \rho \max$ and $\Delta \rho \min \left(\mathrm{e} \AA^{3}\right)$ & 0.68 and -0.60 & 0.50 and -0.74 \\
\hline
\end{tabular}


Egypt. J. Solids, Vol. (29), No. (1), (2006)

Table 2: Fractional atomic coordinates and equivalent isotropic thermal parameters $\left(\AA^{2}\right)$ of compound $\mathbf{1}$, involving non-hydrogen atoms.

\begin{tabular}{|c|c|c|c|c|}
\hline & $\mathbf{x}$ & $\mathbf{y}$ & $\mathbf{z}$ & Ueq \\
\hline N1 & $1.0774(4)$ & $-0.0951(4)$ & $0.09801(15)$ & 0.0387 (19) \\
\hline $\mathrm{C} 2$ & $1.1396(5)$ & $-0.1150(4)$ & $0.04622(19)$ & $0.038(2)$ \\
\hline $\mathrm{C} 3$ & $1.1303(5)$ & $-0.0219(4)$ & $-0.00045(18)$ & $0.037(2)$ \\
\hline $\mathrm{C} 4$ & $1.0452(5)$ & $0.1078(4)$ & $0.00878(19)$ & $0.038(2)$ \\
\hline $\mathrm{C} 5$ & $0.9823(6)$ & $0.1317(5)$ & $0.0636(2)$ & $0.041(2)$ \\
\hline C6 & $0.9986(5)$ & $0.0299(5)$ & $0.10743(18)$ & $0.038(2)$ \\
\hline $\mathrm{C} 7$ & $1.2155(5)$ & $-0.0457(5)$ & $-0.05666(17)$ & $0.037(2)$ \\
\hline $\mathrm{O} 8$ & $1.3190(4)$ & $0.0337(4)$ & $-0.07344(15)$ & $0.060(2)$ \\
\hline O9 & $1.1646(4)$ & $-0.1603(3)$ & $-0.08491(13)$ & $0.0477(17)$ \\
\hline $\mathrm{C} 10$ & $1.2487(7)$ & $-0.1989(5)$ & $-0.13830(18)$ & $0.053(3)$ \\
\hline C11 & $1.1832(8)$ & $-0.1186(7)$ & $-0.1883(2)$ & $0.076(4)$ \\
\hline $\mathrm{C} 12$ & $1.0175(5)$ & $0.2148(4)$ & $-0.03754(19)$ & $0.040(2)$ \\
\hline C13 & $0.9463(6)$ & $0.1743(5)$ & $-0.0901(2)$ & $0.051(3)$ \\
\hline $\mathrm{C} 14$ & $0.9141(6)$ & $0.2760(6)$ & $-0.1323(2)$ & $0.053(3)$ \\
\hline $\mathrm{C} 15$ & $0.9544(6)$ & $0.4179(5)$ & $-0.1226(2)$ & $0.046(2)$ \\
\hline $\mathrm{C} 16$ & $1.0256(6)$ & $0.4598(5)$ & $-0.0716(2)$ & $0.046(2)$ \\
\hline $\mathrm{C} 17$ & $1.0557(6)$ & $0.3593(5)$ & $-0.0291(2)$ & $0.044(2)$ \\
\hline $\mathrm{C} 18$ & $0.9325(5)$ & $0.0504(5)$ & $0.16664(17)$ & $0.038(2)$ \\
\hline C19 & $0.8217(6)$ & $0.1594(5)$ & $0.1779(2)$ & $0.050(3)$ \\
\hline $\mathrm{C} 20$ & $0.7609(7)$ & $0.1762(5)$ & $0.2333(2)$ & $0.060(3)$ \\
\hline $\mathrm{C} 21$ & $0.8075(7)$ & $0.0873(7)$ & $0.2773(2)$ & $0.064(3)$ \\
\hline $\mathrm{C} 22$ & $0.9161(7)$ & $-0.0222(7)$ & $0.2668(2)$ & $0.066(4)$ \\
\hline $\mathrm{C} 23$ & $0.9765(6)$ & $-0.0404(6)$ & $0.2114(2)$ & $0.053(3)$ \\
\hline $\mathrm{Br} 24$ & $1.25859(7)$ & $-0.29011(4)$ & $0.03890(2)$ & $0.0571(3)$ \\
\hline $\mathrm{Cl} 25$ & $0.92031(19)$ & $0.54556(16)$ & $-0.17619(6)$ & $0.0676(8)$ \\
\hline
\end{tabular}


A.M. Moustafa, et al.

Table 3: Fractional atomic coordinates and equivalent isotropic thermal parameters $\left(\AA^{2}\right)$ of compound 2, involving non-hydrogen atoms.

\begin{tabular}{|c|c|c|c|c|}
\hline & $\mathbf{x}$ & $\mathbf{y}$ & $\mathbf{z}$ & $\mathbf{U}_{\text {eq }}$ \\
\hline N1 & $1.0025(3)$ & $0.1828(3)$ & $0.8205(2)$ & $0.0475(16)$ \\
\hline $\mathrm{C} 2$ & $0.9446(3)$ & $0.1662(4)$ & $0.9256(3)$ & $0.048(2)$ \\
\hline $\mathrm{C} 3$ & $1.0064(3)$ & $0.2694(4)$ & $1.0281(3)$ & $0.047(2)$ \\
\hline $\mathrm{C} 4$ & $1.1400(4)$ & $0.3833(3)$ & $1.0234(3)$ & $0.048(2)$ \\
\hline $\mathrm{C} 5$ & $1.2016(3)$ & $0.3954(3)$ & $0.9158(3)$ & $0.050(2)$ \\
\hline $\mathrm{C} 6$ & $1.1271(3)$ & $0.2977(3)$ & $0.8151(3)$ & $0.047(2)$ \\
\hline $\mathrm{C} 7$ & $0.9238(4)$ & $0.2690(4)$ & $1.1313(3)$ & $0.059(2)$ \\
\hline $\mathrm{O} 8$ & $0.8160(3)$ & $0.2780(3)$ & $1.1178(2)$ & $0.0842(19)$ \\
\hline O9 & $0.9880(3)$ & $0.2628(3)$ & $1.2389(2)$ & $0.087(2)$ \\
\hline $\mathrm{C} 10$ & $0.9313(6)$ & $0.2994(10)$ & $1.3543(6)$ & $0.161(6)$ \\
\hline $\mathrm{C} 11$ & $0.8311(11)$ & $0.1753(12)$ & $1.3739(8)$ & $0.207(9)$ \\
\hline $\mathrm{C} 12$ & $1.2176(4)$ & $0.4977(3)$ & $1.1254(3)$ & $0.048(2)$ \\
\hline $\mathrm{C} 13$ & $1.1566(4)$ & $0.5755(4)$ & $1.1747(3)$ & $0.063(2)$ \\
\hline $\mathrm{C} 14$ & $1.2319(5)$ & $0.6842(4)$ & $1.2658(4)$ & $0.072(3)$ \\
\hline $\mathrm{C} 15$ & $1.3703(4)$ & $0.7161(4)$ & $1.3093(3)$ & $0.060(2)$ \\
\hline $\mathrm{C} 16$ & $1.4328(4)$ & $0.6411(4)$ & $1.2622(3)$ & $0.059(2)$ \\
\hline $\mathrm{C} 17$ & $1.3566(4)$ & $0.5338(4)$ & $1.1710(3)$ & $0.055(2)$ \\
\hline $\mathrm{C} 18$ & $1.1831(3)$ & $0.3135(4)$ & $0.6947(3)$ & $0.051(2)$ \\
\hline $\mathrm{C} 19$ & $1.2666(4)$ & $0.4435(4)$ & $0.6580(3)$ & $0.062(2)$ \\
\hline $\mathrm{C} 20$ & $1.3188(4)$ & $0.4562(5)$ & $0.5450(4)$ & $0.080(3)$ \\
\hline $\mathrm{C} 21$ & $1.2854(5)$ & $0.3376(7)$ & $0.4699(4)$ & $0.091(3)$ \\
\hline $\mathrm{C} 22$ & $1.2029(5)$ & $0.2074(5)$ & $0.5050(4)$ & $0.084(3)$ \\
\hline $\mathrm{C} 23$ & $1.1512(4)$ & $0.1949(4)$ & $0.6168(3)$ & $0.068(2)$ \\
\hline $\mathrm{N} 24$ & $0.8187(3)$ & $0.0448(3)$ & $0.9262(3)$ & $0.0564(18)$ \\
\hline $\mathrm{C} 25$ & $0.7446(4)$ & $-0.0463(4)$ & $0.8133(4)$ & $0.075(3)$ \\
\hline $\mathrm{C} 26$ & $0.5863(4)$ & $-0.1189(5)$ & $0.8174(4)$ & $0.083(3)$ \\
\hline $\mathrm{C} 27$ & $0.5453(4)$ & $-0.1951(5)$ & $0.9290(5)$ & $0.090(3)$ \\
\hline $\mathrm{C} 28$ & $0.6311(5)$ & $-0.1001(5)$ & $1.0435(4)$ & $0.086(3)$ \\
\hline $\mathrm{C} 29$ & $0.7877(4)$ & $-0.0339(4)$ & $1.0329(4)$ & $0.071(3)$ \\
\hline $\mathrm{Cl} 30$ & $1.46585(13)$ & $0.85304(12)$ & $1.42398(11)$ & $0.0992(8)$ \\
\hline
\end{tabular}


Tables (4\&5) show selected geometric parameters. In the ring (A), the bond lengths N1-C2 and C2-C3 in $\mathbf{1}$ [1.318(4) and 1.382(4) $\AA$ ] is shorter than the same bonds in 2 [1.343(3) and 1.417(4) $\AA$ ], which may be due to the bromine effect at $\mathrm{C} 2$. The other values of the bond lengths of this ring agree well with the average values reported for the same ring in other compounds $[5,6]$. The longest and shortest bond lengths in ring (D) in 2 are C27$\mathrm{C} 28=1.508(5) \AA$ and $\mathrm{N} 24-\mathrm{C} 25=1.455(4) \AA$, respectively, with mean value 1.487(4) $\AA$. These values reflect the shortened character of the single bonds of the chair configuration of the piperidin ring, which consist well with the reported values $[7,8]$.

Table 4: Bond lengths and bond angles of compound 1.

\begin{tabular}{|l|l|l|l|}
\hline \multicolumn{3}{|c|}{ Bond Length $(\AA)$} & \multicolumn{2}{c|}{ Bond Angle $\left({ }^{\circ}\right)$} \\
\hline C15-Cl & $1.737(3)$ & N1-C6-C18 & $116.2(3)$ \\
\hline C7-C3 & $1.499(4)$ & C13-C12-C17 & $118.5(3)$ \\
\hline C7-O8 & $1.205(4)$ & C6-N1-C2 & $117.4(2)$ \\
\hline C7-O9 & $1.318(4)$ & N1-C2-C3 & $126.6(3)$ \\
\hline C2-Br & $1.915(3)$ & C2-C3-C4 & $116.2(3)$ \\
\hline C2-N24 & $1.385(3)$ & C3-C4-C5 & $117.8(3)$ \\
\hline & & C4-C5-C6 & $121.1(3)$ \\
\hline & & C5-C6-N1 & $120.8(3)$ \\
\hline
\end{tabular}

Table 5: Bond lengths and bond angles of compound 2.

\begin{tabular}{|l|l|l|l|}
\hline \multicolumn{2}{|c|}{ Bond Length $(\AA)$} & \multicolumn{2}{c|}{ Bond Angle $\left({ }^{\circ}\right)$} \\
\hline C15-Cl & $1.733(3)$ & N1-C6-C18 & $116.2(2)$ \\
\hline C7-C3 & $1.500(4)$ & C13-C12-C17 & $117.7(3)$ \\
\hline C7-O8 & $1.193(3)$ & C26-C27-C28 & $110.8(3)$ \\
\hline C7-O9 & $1.332(3)$ & C6-N1-C2 & $118.6(2)$ \\
\hline C2-N24 & $1.377(3)$ & N1-C2-C3 & $122.2(3)$ \\
\hline N24-C25 & $1.455(4)$ & C2-C3-C4 & $118.1(2)$ \\
\hline C25-C26 & $1.505(5)$ & C3-C4-C5 & $118.7(2)$ \\
\hline C26-C27 & $1.497(5)$ & C4-C5-C6 & $119.4(3)$ \\
\hline C27-C28 & $1.508(5)$ & C5-C6-N1 & $122.4(2)$ \\
\hline C28-C29 & $1.503(4)$ & & \\
\hline C29-N24 & $1.456(4)$ & & \\
\hline
\end{tabular}


The value of the bond angle N1-C2-C3 in 1, 126.6(3), is more than the same angle in 2, 122.2(3), which may be also due to the substitution effect at C2. The C6-N1-C2 angle in the two compounds is smaller than $120^{\circ}$ (117.4(2) in 1 and 118.6(2) in 2), as expected for a non-protonated ring system [9]. From the calculations of the best plane passing through the ring (A), it was found that the maximum deviations are those of the atoms $\mathrm{C} 4=-0.0106(43) \AA$ in $\mathbf{1}$, and $\mathrm{C} 3=-0.0390(33) \AA$ in 2 . These values mean that the ring (A) exhibits planer configuration. Both rings (B) and (C) in the two compounds are planer within themselves.

The values of the torsion angles C11-C10-O9-C7 of compounds $\mathbf{1}$ and 2 are $-85.9(5)$ and $90.9(7)^{\circ}$, respectively; describe the orientation of the methyl group with respect to the carboxylate. These values mean that, in $\mathbf{1}$ the ethyl group oriented towards the ring (B). This is in contrary to compound $\mathbf{2}$ where the ethyl group is oriented towards the piperadine ring as indicated from the interatomic distances $\mathrm{C} 28-\mathrm{H} 11 \mathrm{C}=3.435(3), \mathrm{C} 29-\mathrm{H} 11 \mathrm{C}=3.517(3), \mathrm{O} 8-\mathrm{H} 29 \mathrm{~B}$ $=2.811(2)$ and $\mathrm{O} 8-\mathrm{H} 28 \mathrm{~B}=2.999(2) \AA$.

The small dihedral angles between the ring $(\mathrm{C})$ and ring (A), they are $12.57(3.420)^{\circ}$ and $29.65(3.497)^{\circ}$ in $\mathbf{1}$ and 2 , respectively, may assist the delocalization of the pyridine ring. The dihedral angles between ring (B) and ring (A) are $54.80(3.375)^{\circ}$ and $57.59(3.390)^{\circ}$ in $\mathbf{1}$ and $\mathbf{2}$, respectively. The packing diagram is shown in Fig. (3). A network of intermolecular contact stabilizes the structure of the two compounds with different symmetry codes in each compound; C-H---C, C-H---O and C-H---Cl in 1 and C-H---O and C-H--$\mathrm{C}$ in 2 (Tables 6 and 7). 

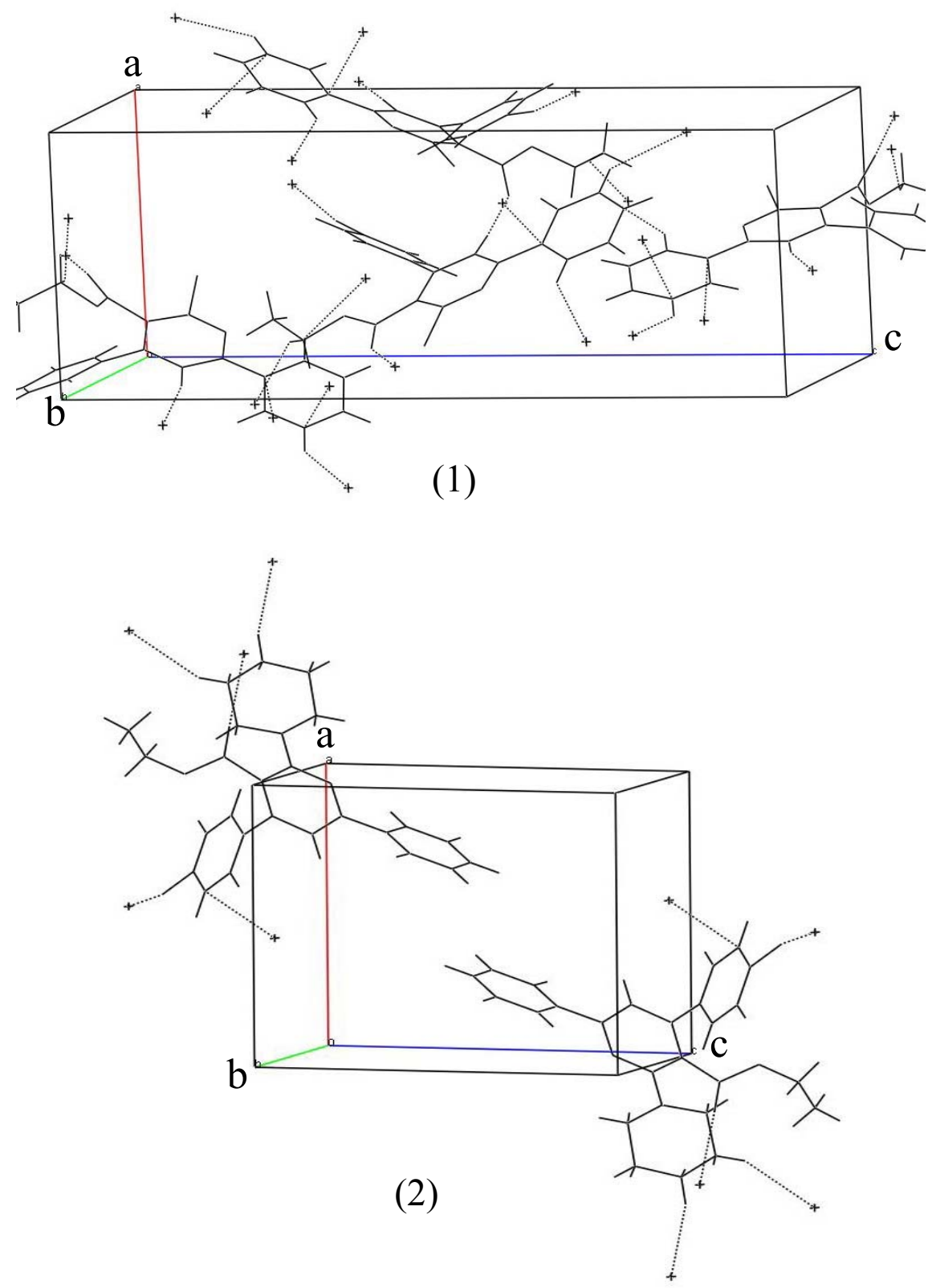

Fig. 3: The molecular packing of compound (1) and (2) with the C-H---C, C-H---O and $\mathrm{C}-\mathrm{H}---\mathrm{Cl}$ interactions shown as dashed line. 
Table 6: Hydrogen-bonding geometry for compound 1.

\begin{tabular}{|l|l|l|l|l|}
\hline & \multicolumn{3}{|c|}{ Bond Length $(\AA)$} & Bond Angle $\left(^{\circ}\right)$ \\
\cline { 2 - 5 } & D-H & H...A & D...A & D-H...A \\
\hline $\mathrm{C} 20-\mathrm{H} 20^{\mathrm{i}} \ldots \ldots \ldots . \mathrm{C} 25$ & $0.960(4)$ & $2.828(9)$ & $3.653(5)$ & $144.6(3)$ \\
$\mathrm{C} 5-\mathrm{H} 5^{\mathrm{iii}} \ldots \ldots \ldots . \mathrm{O} 8$ & $0.960(3)$ & $2.461(3)$ & $3.400(3)$ & $165.9(2)$ \\
$\mathrm{C} 10-\mathrm{H} 10 \mathrm{~B}^{\mathrm{iv}} \ldots \ldots . \mathrm{C} 18$ & $0.960(3)$ & $2.873(3)$ & $3.666(4)$ & $140.6(2)$ \\
$\mathrm{C} 23-\mathrm{H} 23^{\mathrm{v}} \ldots \ldots \ldots . \mathrm{C} 20$ & $0.960(4)$ & $2.874(4)$ & $3.663(4)$ & $140.2(2)$ \\
\hline
\end{tabular}

(i) $3 / 2-\mathrm{x}, 1-\mathrm{y}, \mathrm{z}-1 / 2$; (iii) $1 / 2+\mathrm{x}, 1 / 2-\mathrm{y},-\mathrm{z}$; (iv) $\mathrm{x}-1 / 2,-1 / 2-\mathrm{y},-\mathrm{z}$; (v) $2-\mathrm{x}, 1 / 2+\mathrm{y}, 1 / 2-\mathrm{z}$

Table 6: Hydrogen-bonding geometry for compound 2.

\begin{tabular}{|l|l|l|l|l|}
\hline \multirow{2}{*}{} & \multicolumn{3}{|c|}{ Bond Length $(\AA)$} & Bond Angle $\left(^{\circ}\right)$ \\
\cline { 2 - 5 } & D-H & H....A & D ...A & D-H...A \\
\hline C27-H27A ${ }^{\mathrm{i}} \ldots \ldots$ OO & $0.960(3)$ & $2.590(2)$ & $3.510(2)$ & $160.66(9)$ \\
C28-H28A ${ }^{\text {iv } \ldots . . . C 16 ~}$ & $0.960(4)$ & $2.876(3)$ & $3.769(3)$ & $155.27(7)$ \\
\hline
\end{tabular}

(i) $1-\mathrm{x},-\mathrm{y}, 2-\mathrm{z}$; (iv) $1+\mathrm{x}, 1+\mathrm{y}, \mathrm{z}$

\section{Conclusion:}

It is concluded that, geometrical parameters of the two investigated compounds were comparable with the predetermined crystal structures of similar compounds. Also, the different constituents attached to the pyridine ring affect on its bond lengths and angles. The structures of the two compounds stabilize due to the existence of a network of intermolecular contacts.

\section{References:}

1. Z. Otwinowski and W. Minor. In Methods in Enzymology, 276, edited by C. W. Carter, Jr. \& R. M. Sweet; Academic Press, New York, p. 307, (1997).

2. A. Altomare, M. C. Burla, M. Camalli, G. L. Cascarano, C. Giacovazzo, A. Guagliardi, A. G. G. Moliterni, and R. Spagna, J. Appl. Cryst. 32, 115 (1999).

3. S, Mackay, C. J. Gilmore, C. Edwards, N. Stewart, and K. Shankland, maXus Computer Program for the Solution and Refinement of Crystal Structures. Bruker Nonius, The Netherlands, MacScience, Japan \& The University of Glasgow, (1999). 
4. C. K. Johnson. ORTEP--II. A Fortran Thermal--Ellipsoid Plot Program. Report ORNL-5138. Oak Ridge National Laboratory, Oak Ridge, Tennessee, USA, (1976).

5. H. U. Patel, Acta Cryst. C59, o30 (2003).

6. W. J. Tong, L. Liu, Q.-J. Meng, Y.-Z. Li and Y.-G. Yao, Acta Cryst. E59, m3 (2003).

7. S. Bhaskaran, S. Selvanayagam, D. Velmurugan, K. Ravikumar, M. Anniyappan,

D. Muralidharan and P. T. Perumal, Acta Cryst. E59, o1301 (2003).

8. D. A. Parrish, J. R. Deschamps, F. Jiang and N. T. Zaveri, Acta Cryst. E60, o1253 (2004).

9. R. Ghosh, and S. H. Simonsen, Acta Cryst. C49, 1031 (1993). 